\title{
Synthesis and properties of acetamidinium salts
}

\author{
Zdeněk Jalový ${ }^{1 *}$, Robert Matyášs ${ }^{1}$, Jan Ottis ${ }^{1}$, Aleš Rưžička ${ }^{2}$, Petr Šimůnek ${ }^{3}$ and Miroslav Polášek ${ }^{4}$
}

\begin{abstract}
Background: Acetamidines are starting materials for synthesizing many chemical substances, such as imidazoles, pyrimidines and triazines, which are further used for biochemically active compounds as well as energetic materials. The aim of this study was to synthesise and characterise a range of acetamidinium salts in order to overcome the inconvenience connected with acetamidinium chloride, which is the only commercially available acetamidinium salt.

Results: Acetamidinium salts were synthesised and characterised by elemental analysis, mass spectrometry, NMR and in the case of energetic salts - DTA. The structures of previously unknown acetamidinium salts were established by $X$ ray diffraction analysis. Hygroscopicities in $90 \%$ humidity of eight acetamidinium salts were evaluated.

Conclusions: The different values of hygroscopicity are corroborated by the structures determined by X-ray analysis. The acetamidinium salts with 2D layered structures (acetamidinium nitrate, formate, oxalate and dinitromethanide) show a lack of hygroscopicity, and the compounds with 3D type of structure (acetamidinium chloride, acetate, sulphate and perchlorate) and possessing rather large cavities are quite hygroscopic.
\end{abstract}

\section{Background}

Acetamidines are starting materials in the synthesis of many chemical substances, such as imidazoles, pyrimidines and triazines which are further used for biochemically active compounds [1-5]. In the field of energetic materials, acetamidine is a starting material for the synthesis of 2-methoxy-2-methylimidazolidine-4,5-dione [6] and 2-methylpyrimidine-4,6-diol [7-9]. Both are further transformed to 2,2-dinitroethene-1,1-diamine (FOX-7, DADNE), which is an energetic material with low sensitivity to external stimuli $[6,10]$. The free base acetamidine is hygroscopic. It decomposes into ammonia and acetonitrile at higher temperatures [11], and produces acetamidinium carbonate during one day at room temperature when stored in contact with air [12]. Therefore, it is unsuitable as a starting material for synthesis and the use of an acetamidinium salt is necessary.

The most commonly used and commercially available salt of acetamidine is acetamidinium chloride (1). It is prepared by the Pinner method from acetonitrile and alcohol in the presence of hydrogen chloride, followed by addition of ammonia to the intermediate iminoether

\footnotetext{
* Correspondence: zdenek.jalovy@upce.cz

'University of Pardubice, Faculty of Chemical Technology, Institute of Energetic Materials, Studentská 95, CZ-532 10 Pardubice, Czech Republic Full list of author information is available at the end of the article
}

[13]. Reaction of acetonitrile with cobalt or nickel nitrates and oximes gives acetamidinium nitrate (2) $[14,15]$. An easily accessible acetamidine salt is acetamidinium acetate (3), prepared by the reaction of triethyl orthoacetate, ammonia and ammonium acetate [16]. The method is convenient, both for laboratory and industrial use or the acetate may be further transformed into other salts, e.g. formate (4) [17] sulphate (5) [18] or dinitromethanide (6) [19]. Many synthetic routes for acetamidines have been reviewed [20,21].

The main disadvantage of acetaminium chloride is its relatively high hygroscopicity. The release of the free base in methanol by the use of sodium methoxide will produce sodium chloride, which is partly soluble in this solvent $(\sim 1 \mathrm{~g} / 100 \mathrm{ml})$ [22]. The presence of any chloride sourse is unfavourable in certain syntheses, e.g. nitrations, and its complete removal is tedious [6].

Here we describe the synthesis, X-ray structure, hygroscopicity and thermal stability of some of the acetamidine salts listed in Figure 1.

\section{Results and Discussion Synthesis}

The procedure for the preparation of acetamidinium sulphate (5) via an ion exchange reaction from acetamidinium chloride (1) was earlier described by us [22].
() ChemistryCentral

๑ 2011 Jalový et al, ilicensee BioMed Central Ltd. This is an open access article distributed under the terms of the Creative Commons Attribution License (http://creativecommons.org/licenses/by/2.0), which permits unrestricted use, distribution, and reproduction in any medium, provided the original work is properly cited. 


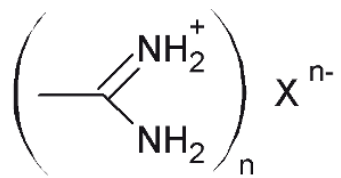
$1 \mathrm{X}=\mathrm{Cl}, \mathrm{n}=1$
$4 \mathrm{X}=\mathrm{HCOO}, \mathrm{n}=1$
$7 \mathrm{X}=(\mathrm{COO})_{2}, \mathrm{n}=2$
$2 \mathrm{X}=\mathrm{NO}_{3}, \mathrm{n}=1$
$5 \mathrm{X}=\mathrm{SO}_{4}, \mathrm{n}=2$
$8 \mathrm{X}=\mathrm{ClO}_{4}, \mathrm{n}=1$
$3 \mathrm{X}=\mathrm{CH}_{3} \mathrm{COO}, \mathrm{n}=1$
$6 \mathrm{X}=\mathrm{CH}\left(\mathrm{NO}_{2}\right)_{2}, \mathrm{n}=1$
$9 \mathrm{X}=\mathrm{HSO}_{4}, \mathrm{n}=1$

Figure 1 List of acetamidinium salts studied.

This procedure was now used for the synthesis of the nitrate (2) and the oxalate (7). Thus, it may be considered as a universal method for the preparation of acetamidine salts starting from 1 (Figure 2).

The method used in the preparation of (5) [18], starting from acetamidine acetate and based on the reaction of the latter with an acid stronger than acetic acid, was now successfully used in the preparation of acetamidinium perchlorate (8) from 3 and perchloric acid. Acetamidinium perchlorate (8)was also prepared from 5 by an ion exchange reaction with barium perchlorate in water (Figure 3).

The method starting with acetamidinium acetate (3) based on the reaction with a stronger acid than the one we used (acetic acid) for acetamidinium sulphate (5) [18] was now successfully used for preparation of acetamidinium perchlorate (8). This salt was also prepared from 5 by an ion exchange reaction with barium perchlorate in water (Figure 3).
Acetamidinium formate (4) was prepared from trimethyl orthoacetate and ammonium formate. A similar method has been published earlier by Taylor for preparation of 3 [16].

\section{Hygroscopicities}

Hygroscopicities of acetamidinium salts, determined at $90 \%$ humidity and $30^{\circ} \mathrm{C}[23]$ and the comparison of these results with ammonium acetate (10), guanidinium nitrate (11) and guanidinium chloride (12) are represented as the weight increase compared with the weight of the original sample, expressed in \%. The results are given in Figure 4 and values for certain days are presented in Table 1. In the case of compounds with known structure determined by X-ray diffraction techniques, information about the spatial structure is also included. The influence of the structure on hygroscopicity is discussed later.

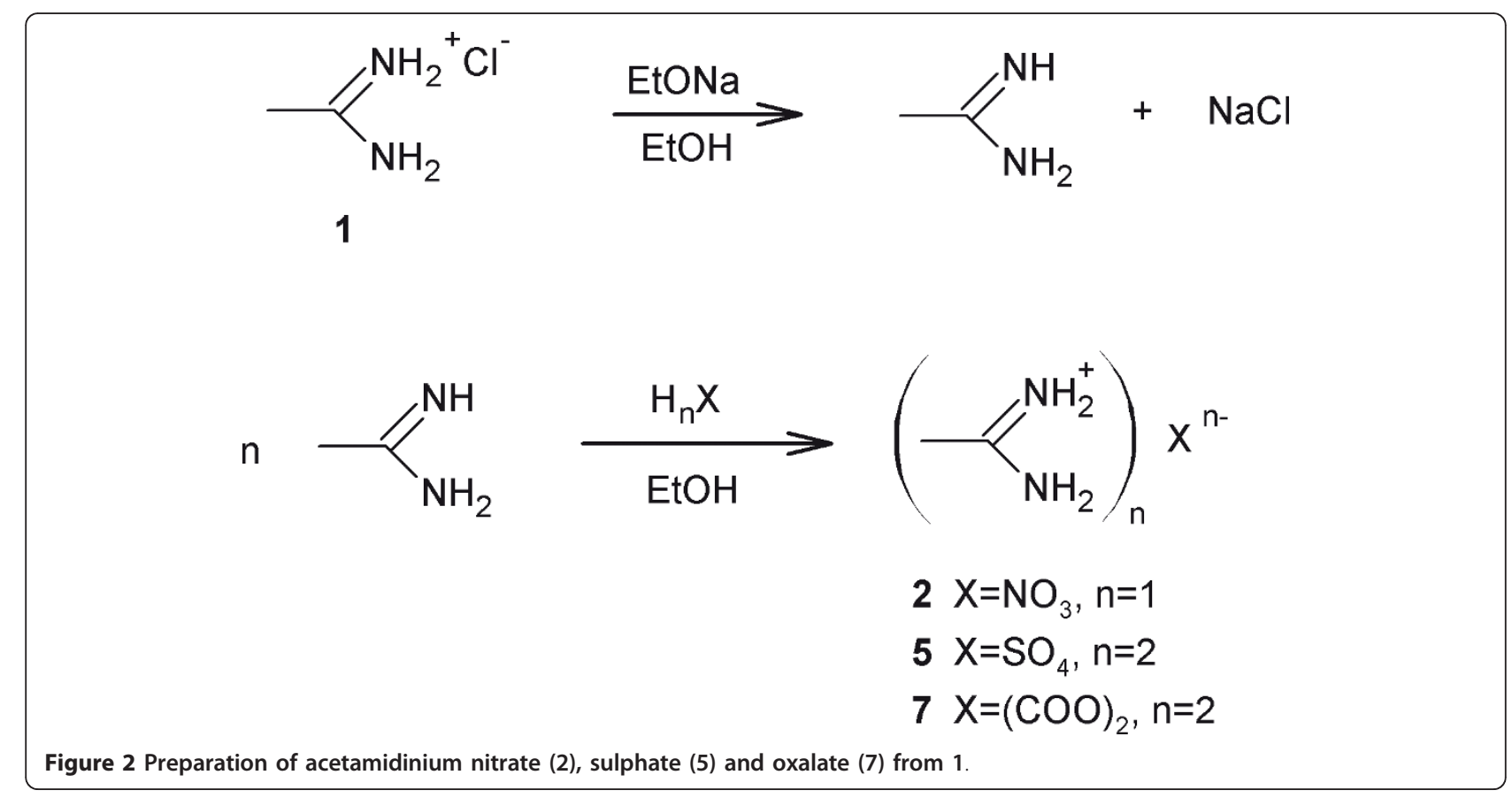




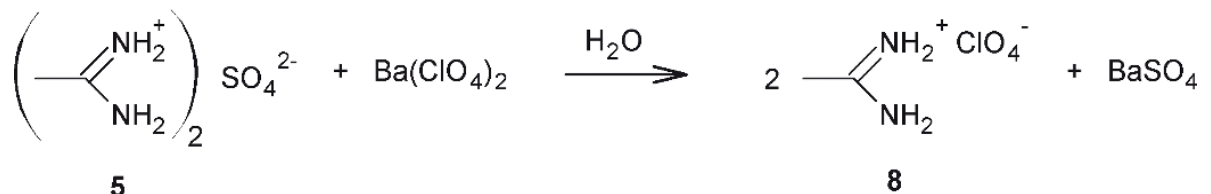

Figure 3 Preparation of acetamidinium perchlorate (8) from 5

The nitrate (2), formate (4), dinitromethanide (6) and oxalate (7) salts are almost anhygroscopic. The chloride (1), acetate (3), sulphate (5) and hydrogensulphate (9) compounds are hygroscopic. The hygroscopicity of acetamidinium chloride (1) is almost the same as for guanidinium chloride (12), and acetamidinium acetate (3) is very similar to ammonium acetate (10).

\section{X-ray crystallography}

The acetamidinium cation is frequently used as a counterion for a wide variety of anions like simple halogenides, carboxylates, complex metal anions and others. The parent acetamidine reveals large cavities and an extensive system of hydrogen bonding within the structure. The distances between the pivot carbon atom and the amino and imido nitrogen atoms are rather distinct (1.344 $\AA$ for $\mathrm{C}-\mathrm{NH}_{2}$ and $1.298 \AA$ for $\mathrm{C}=\mathrm{NH}$ group) [24].

The hydrogen bridging in one of the polymorphs of acetamidinium (2-hydroxyethoxy)acetate [25], acetamidinium chloride (1) [26] and acetamidinium sulphate (5) [18] revealed 3D structures with large cavities. On the other hand, acetamidinium tetrazolate [27] and acetamidinium dinitromethanide (6) [19] show the staircase-like 2D structures. Interesting examples are acetamidinium hexafluorosilicates, germanates, stannates and titanates [28] or the Re-Se cluster-acetamidinium adduct [29], where multicentre NH...F or NH...Se contacts were found. For two of the compounds studied, the molecular structures were determined by X-ray crystallography techniques. Acetamidinium oxalate (7, Figure 5) has a 2D structure with layers interconnected with not too extensive $\mathrm{H}$-bonding. Acetamidinium perchlorate (8, Figure 6) has a 3D structure with layers interconnected with extensive $\mathrm{H}$-bonding.

The perchlorate and oxalate structures are rather unique in the set of acetamidinium structures determined, the distances between the pivot carbon atom and the $\mathrm{NH}_{2}$ moiety are rather different - 1.323(3) $\AA$ for the $\mathrm{C}-\mathrm{NH}_{2}$ group bonded by $\mathrm{H}$-bonds only to one oxygen atom of the perchlorate ion, and 1.297(4) $\AA$ for the $\mathrm{C}-\mathrm{NH}_{2}$ group bonded by two $\mathrm{H}$-bonds to the perchlorate ion. In the oxalate structure, the differences between these groups are even greater 1.339(5) $\AA$ and 1.280(5) $\AA$, which disagree with a delocalisation concept and the data found in the literature (1.302-1.312 $\AA$ ). In

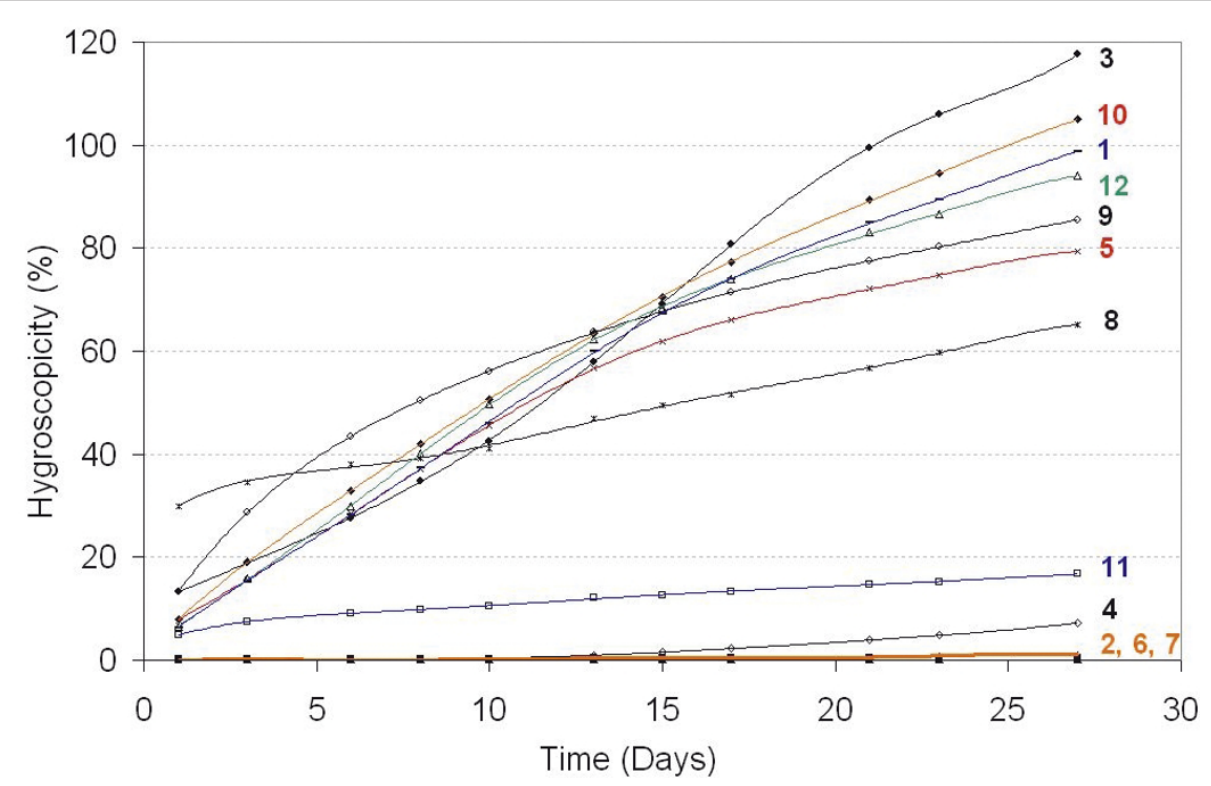

Figure 4 Hygroscopicities of acetamidinium salts (1-8) and comparison with ammonium acetate (9), guanidinium nitrate (11) and guanidinium perchlorate (12). 
Table 1 Hygroscopicities of acetamidinium salts and other selected salts.

\begin{tabular}{llllll}
\hline Compound & Structure & \multicolumn{5}{l}{ Hygroscopicity (\%) } \\
& & $\mathbf{1}$ day & $\mathbf{7}$ days & $\mathbf{1 4}$ days & $\mathbf{2 1}$ days \\
\hline $\mathbf{1}$ & $3 \mathrm{D}$ & 6 & 33 & 64 & 85 \\
$\mathbf{2}$ & 2D & $<1$ & $<1$ & $<1$ & $<1$ \\
$\mathbf{3}$ & $3 \mathrm{D}$ & 13 & 31 & 64 & 99 \\
$\mathbf{4}$ & 2D & $<1$ & $<1$ & 1 & 4 \\
$\mathbf{5}$ & 3D & 8 & 33 & 59 & 72 \\
$\mathbf{6}$ & 2D & 0 & $<1$ & $<1$ & $<1$ \\
$\mathbf{7}$ & 2D & $<1$ & $<1$ & $<1$ & $<1$ \\
$\mathbf{8}$ & 3D & 30 & 39 & 48 & 57 \\
$\mathbf{9}$ & & 13 & 47 & 66 & 78 \\
$\mathbf{1 0}$ & 3D & 7 & 35 & 66 & 83 \\
$\mathbf{1 1}$ & 2D & 5 & 10 & 12 & 15 \\
$\mathbf{1 2}$ & 3D & 8 & 37 & 67 & 89 \\
\hline
\end{tabular}

these groups, the $\mathrm{H}$-bonds to the oxalate moiety are equidistant.

The molecular structure of the oxalate is made up of two mutually similar acetamidinium units and one oxalate ion. All these ions in both compounds are interconnected by extensive hydrogen bonding systems. In the oxalate (7), eight- and fourteen-membered rings are formed (Figure $7)$. The twenty two-membered rings are the main element of the perchlorate (8) structure (Figure 8).

From a study of the above mentioned data and motifs, in combination with the data in Table 1 on the hygroscopicities of the compounds, it is clear that the compounds with layered 2D (counterions linked by $\mathrm{H}$-bridges) structures $(2,4,6,7$, and 11: for 7 , see Figure 9$)$ are not hygroscopic. On the other hand, the compounds that display 3D structures $(\mathbf{1}, \mathbf{3}, \mathbf{5}$, and $\mathbf{8}$ : for $\mathbf{8}$, see Figure 10$)$ have rather high hygroscopicities. This is probably caused by an easier incorporation of water molecules into the larger cavities in the compounds with 3D structure, compared to the intercalation into the compounds with 2D structures.

\section{NMR spectroscopy}

NMR data for acetamidinium salts 2, 4, 7 and 8 are summarised in Table 2. A closer inspection of the proton NMR spectra measured in $\mathrm{D}_{2} \mathrm{O}$ revealed that there is an equilibrium between deuterated and non-deuterated

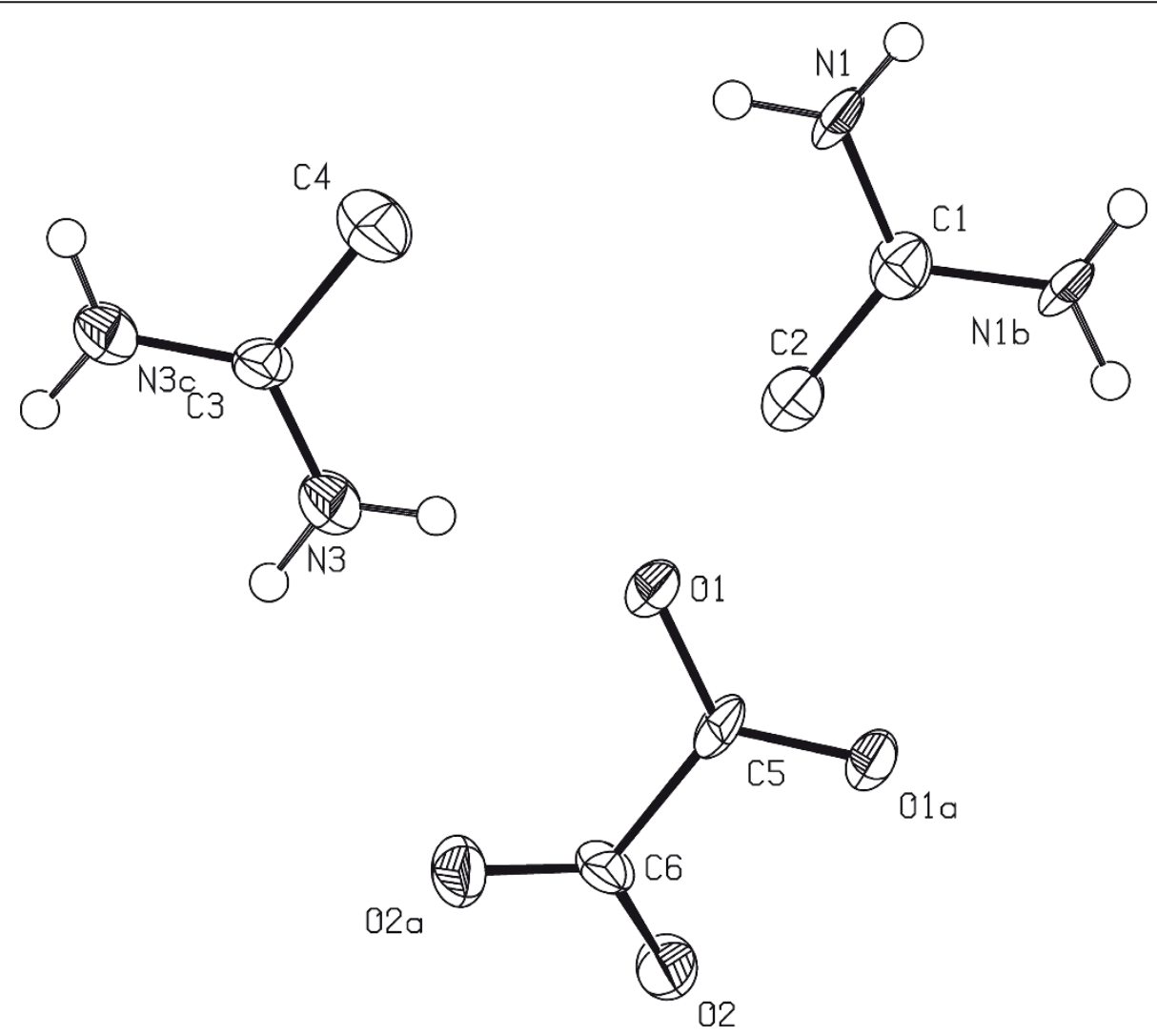

Figure 5 ORTEP view of compound 7 showing the thermal ellipsoids at $50 \%$ probability (arbitrary spheres for $\mathrm{H}$ atoms, methyl $\mathrm{H}$ atoms are omitted for clarity); selected bond lengths $(\AA)$ and angles ( $\left.{ }^{\circ}\right): 01$ C5 1.257(4), 02 C6 1.248(4), C6 C5 1.551(3), C2 C1 1.465(8), C1 N1b 1.339(5), C3 N3 1.280(5), C3 N3c 1.280(5), C3 C4 1.518(8), N1 C1 N1b 117.7(5), N1 C1 C2 121.1(3), N3 C3 N3C 124.2(5), N3 C3 C4 117.9(3). 

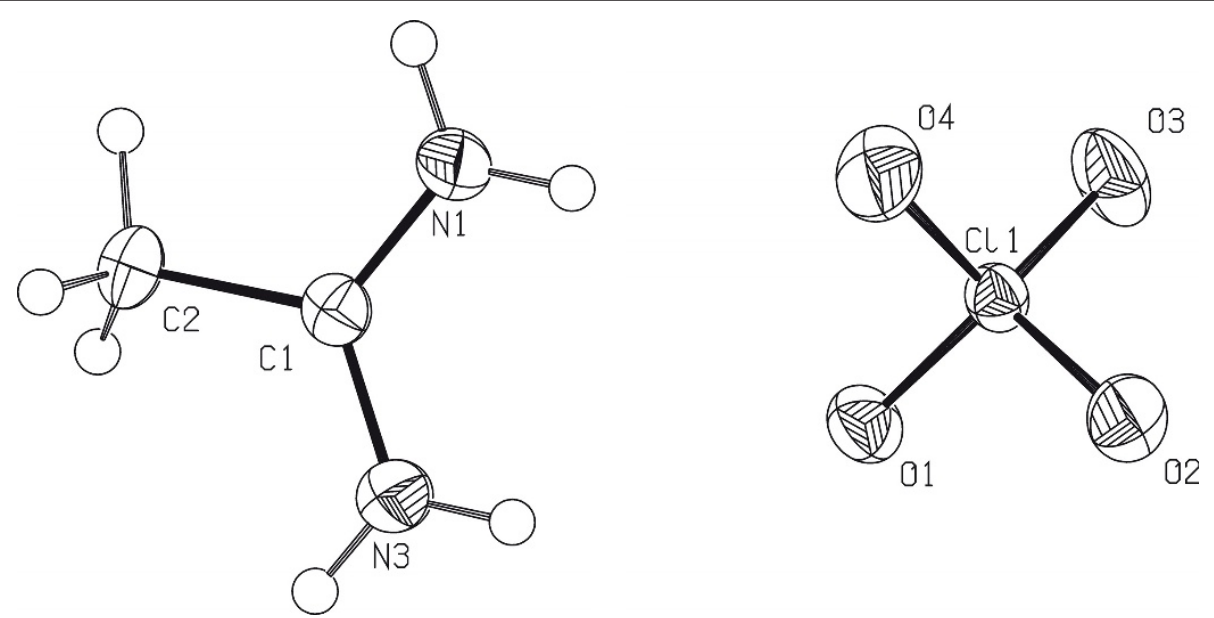

Figure 6 ORTEP view of compound 8 showing the thermal ellipsoids at $50 \%$ probability (arbitrary spheres for $\mathrm{H}$ atoms); selected bond lengths $(\AA)$ and angles $\left(^{\circ}\right)$ : N3 C1 1.323(3), C1 N1 1.297(4), C1 C2 1.481(3), N1 C1 N3 120.9(3), N1 C1 C2 119.7(2), N3 C1 C2 119.3(3).

molecules (strongly decreased intensity of the signals of the acidic protons). The equilibrium is shifted almost entirely to the side of the deuterated sample (approximately $98 \%$ ). There is a contradiction between these observations and those published by Kopylovich [14], where no deuteration was described and two signals per $2 \mathrm{H}$ were observed.
On the other hand, the position of the equillibrium is reversed in DMSO-d6 where approximately $90 \%$ of the non-deuterated form can be found for all the samples measured.

In all cases (excluding 4 in DMSO-d6), two separated broadened signals belonging to the $2 \times \mathrm{NH}_{\mathrm{a}} \mathrm{H}_{\mathrm{b}}$ arrangement were observed, probably due to the delocalisation

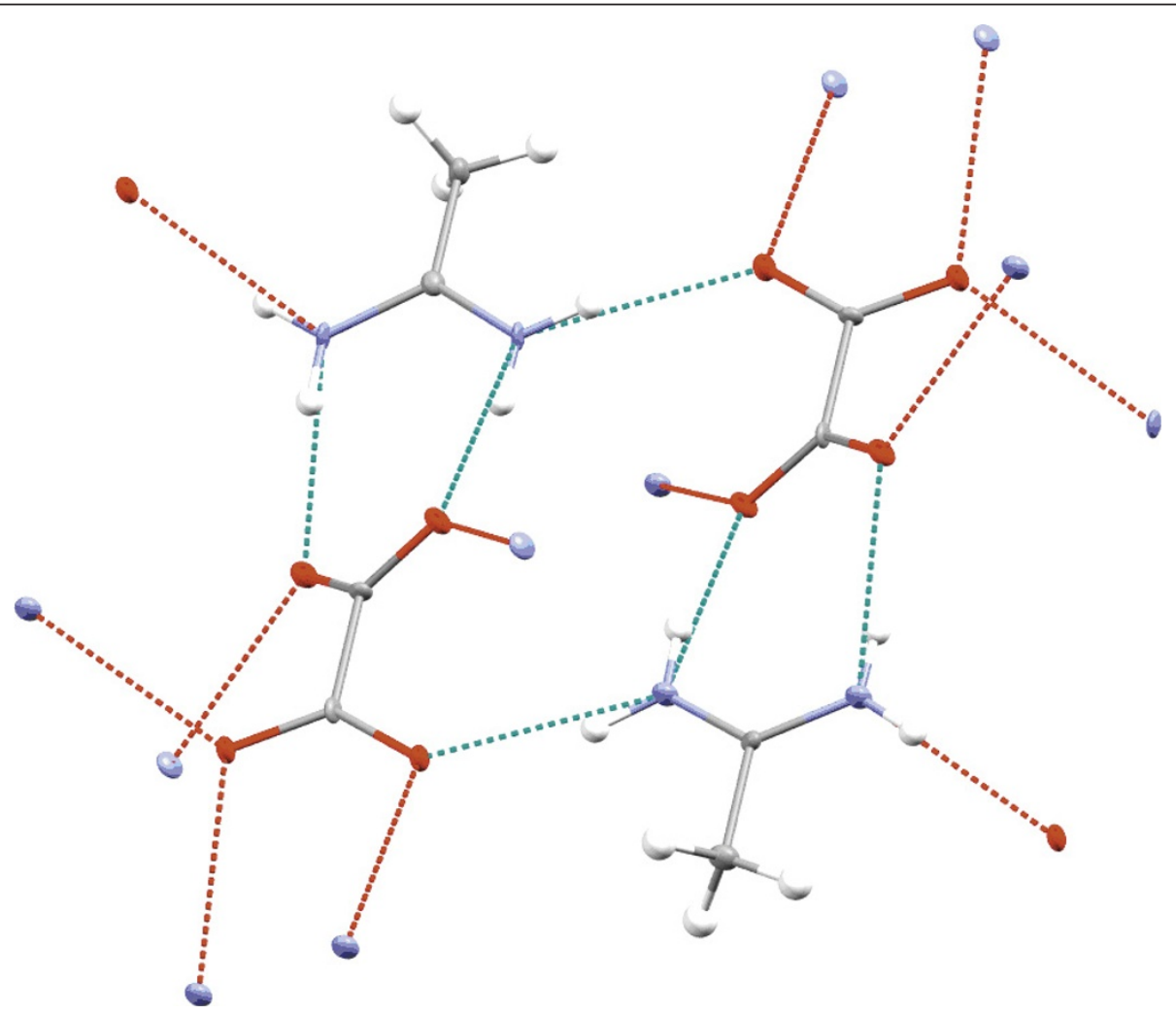

Figure 7 View of hydrogen bridging in 7. Hydrogen bonds (D-H...A distances ( $\AA$ ), and angles ( $\left.{ }^{\circ}\right)$ ): N3...O1 2.893(5) 163.0; N1...O2 2.829(6) 163.8; $\mathrm{N} 1 \mathrm{~b} . . . \mathrm{O} 22.854(5)$ 157.5; N3c...O1 2.825(5). Nitrogen atoms are in blue, oxygen in red and hydrogen in white. 


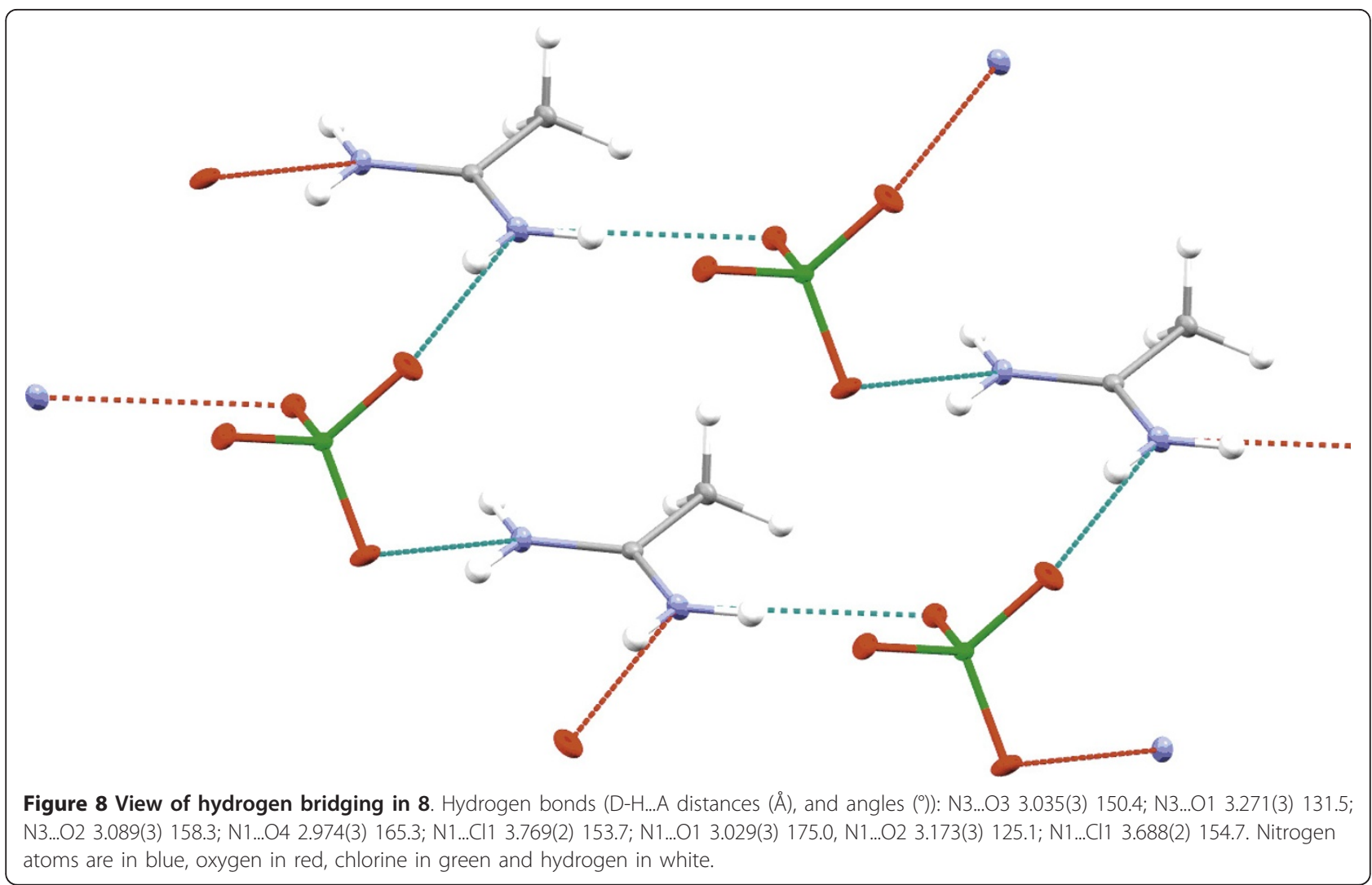

of the positive charge throughout the amidinium group. The only exception is acetamidinium formate 4 in DMSO-d6 where one broad signal comprising all four $\mathrm{NH}$ protons was detected. This is in accordance with the observation published by Krechl [17] and similar to the results obtained by Tominey [27] for acetamidinium tetrazolate complexes. This may be caused by different interactions between the formate anion and amidinium group in defferent solvents. The interactions inside some acetamidinium complexes were studied by Tominey and Krechl by means of NMR, X-ray analysis and quantum chemical treatment $[17,27]$.

\section{Differential thermal analysis}

Acetamidinium nitrate (2), acetamidinium dinitromethanide (6) and acetamidinium perchlorate (8) are energetic materials. Their potential use is in pyrotechnic applications where they may replace guanidinium salts (nitrate or perchlorate). The difference is the higher carbon content of acetamidinium salts compared to the analogous guanidinium ones (replacement of the amino group in guanidines by a methylgroup). Nevertheless, acetamidinium salts still have a relatively high nitrogen content. Compounds $\mathbf{6}$ and $\mathbf{8}$ have acceptable decomposition temperatures measured by differential thermal analysis (DTA). Both the nitrate $\mathbf{2}$ and the perchlorate $\mathbf{8}$ decompose on melting. Thus, the decomposition temperatures of $\mathbf{2}$ and $\mathbf{8}$ are considered as being $183^{\circ} \mathrm{C}$ and $248^{\circ} \mathrm{C}$, respectively (Figure 11). The maxima of decompositions for $\mathbf{2}$ and $\mathbf{8}$ are $255^{\circ} \mathrm{C}$ and $390^{\circ} \mathrm{C}$, respectively. For comparison, guanidinium nitrate starts to decompose at $270^{\circ} \mathrm{C}$ and guanidinium perchlorate at $350^{\circ} \mathrm{C}$, using the same thermal stability device.

\section{Conclusions}

Acetamidinium salts were synthesised and characterised by elemental analysis, electrospray mass spectrometry, NMR and, in the case of energetic salts, by DTA. The structures of previously unknown acetamidines have been proved by X-ray diffraction analysis. Hygroscopicities in $90 \%$ humidity of eight acetamidinium salts have been evaluated. The different values of hygroscopicity are corroborated by the structures determined by X-ray analysis: acetamidinium salts with $2 \mathrm{D}$ layered structures are not hygroscopic while acetamidinium salts with 3D layered structures are quite hygroscopic.

\section{Experimental Caution}

Acetamidines 2, 6, and 8 are explosives, sensitive to mechanical stimuli and heat, and should be handled with care. 


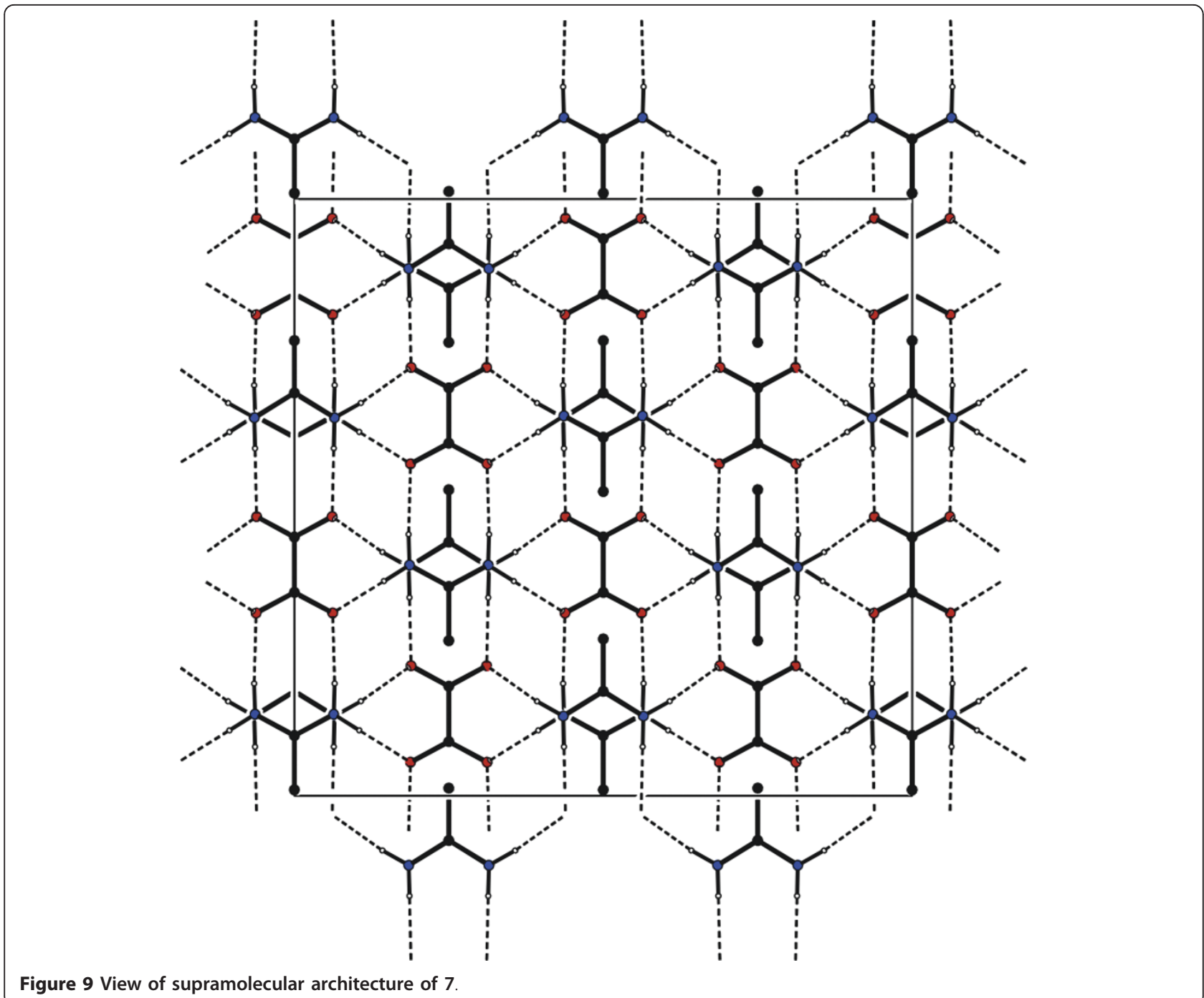

NMR spectra were measured using a Bruker AVANCE III spectrometer operating at $400.13 \mathrm{MHz}\left({ }^{1} \mathrm{H}\right)$ and 100.61 $\mathrm{MHz}\left({ }^{13} \mathrm{C}\right)$. The proton spectra in deuterium oxide were calibrated on the HDO signal of the solvent $(\delta=4.80)$ whereas the spectra in DMSO-d6 were standardised on the residual signal of the solvent $(\delta=2.50)$. Carbon spectra in $\mathrm{D}_{2} \mathrm{O}$ were standardised on internal neat methanol $(\delta=$ 49.50, value taken from [30] and the spectra in DMSO-d6 were calibrated on the middle of the solvent multiplet $(\delta=$ 39.61). The carbon spectra were measured with broadband proton decoupling.

The electrospray (ESI) mass spectra were measured on a Quattro Premiere XE tandem quadrupole mass spectrometer (Waters) equipped with a $\mathrm{T}$-wave ${ }^{\mathrm{TM}}$ collision cell in both positive (ESI+) and negative (ESI-) ion mode. Typical ion source conditions were as follows. ESI+: capillary voltage $3.7 \mathrm{kV}$, cone voltage: $30 \mathrm{~V}$, source temperature: $100^{\circ} \mathrm{C}$, desolvation temperature: $200^{\circ} \mathrm{C}$, desolvation gas: $\mathrm{N}_{2}\left(100 \mathrm{l} \mathrm{hr}^{-1}\right)$; ESI-: capillary voltage 2.5 $\mathrm{kV}$, cone voltage: $30 \mathrm{~V}$, source temperature: $100^{\circ} \mathrm{C}$, desolvation temperature: $200^{\circ} \mathrm{C}$, desolvation gas: $\mathrm{N}_{2}(200 \mathrm{l} \mathrm{hr}$ $\left.{ }^{1}\right)$. Approximately $10^{-4} \mathrm{~mol} \mathrm{l}^{-1}$ solutions of acetamidine salts in water were directly infused into the electrospray ion source using the built-in syringe pump at a flow rate of $5 \mu \mathrm{min}^{-1}$. Generally, in the ESI+ mass spectra, the protonated acetamidine (denoted as $\mathrm{AH}^{+}$) was observed together with the less abundant ions of the general formula $\mathrm{M}_{\mathrm{n}} \mathrm{AH}^{+}$, where $\mathrm{M}$ is a molecule of the salt consisting of acetamidine $\mathrm{A}\left(\mathrm{CH}_{3} \mathrm{C}(\mathrm{NH}) \mathrm{NH}_{2}\right)$ and acid $\mathrm{X}$ (for example $\mathrm{HNO}_{3}$ ). Similarly in the ESI- mass spectra, the deprotonated acids $(\mathrm{X}-\mathrm{H})^{-}$and cluster ions $\mathrm{M}_{\mathrm{n}}(\mathrm{X}-\mathrm{H})^{-}$ were observed.

The thermal analysis was studied using differential thermal analyzer DTA 550Ex (OZM Research). The 50 mg samples were tested in open glass microtest tubes (in contact with air) and the heating rate was $5^{\circ} \mathrm{C} \mathrm{min}^{-1}$. 


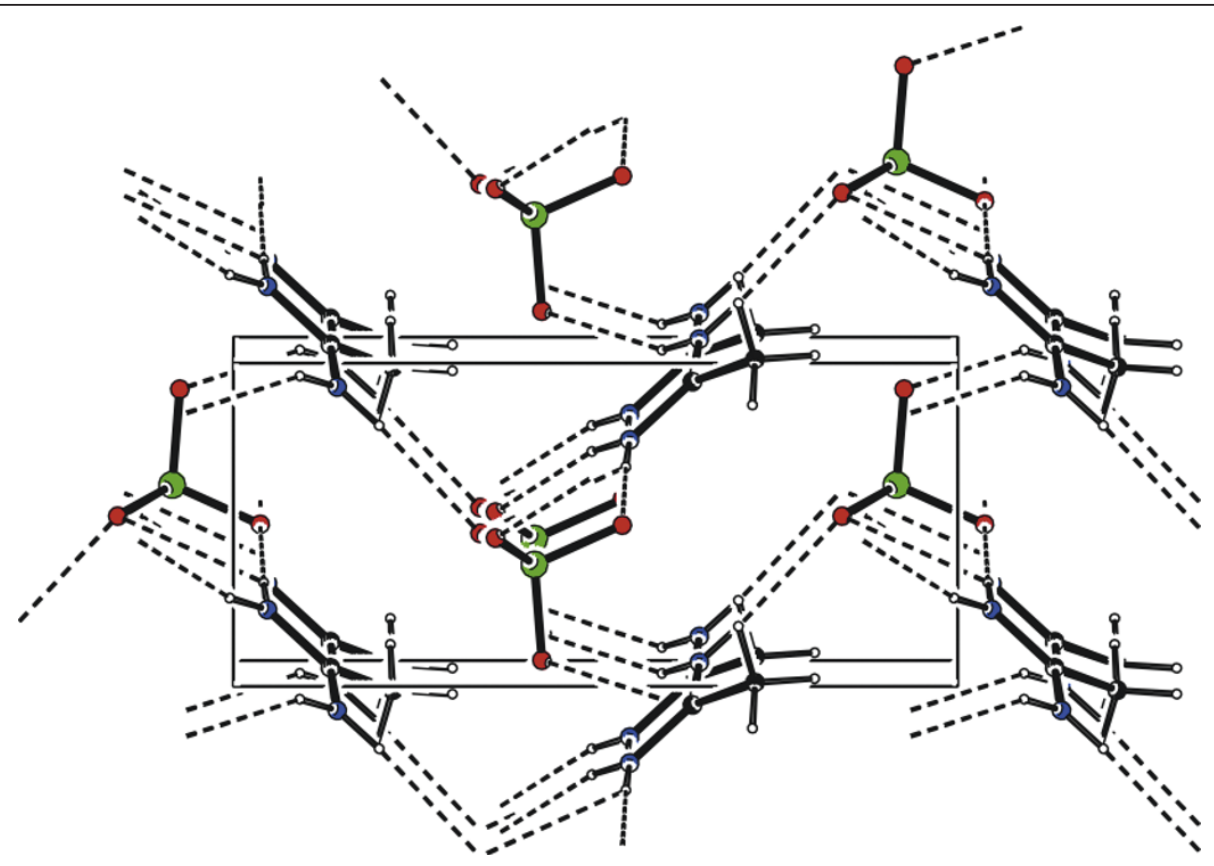

Figure 10 View of supramolecular architecture of 8.

The melting points were measured on a Kofler bench and are uncorrected.

Acetamidinium nitrate (2) Sodium (3.36 g, 146.2 $\mathrm{mmol})$ was gradually dissolved in ethanol $(95 \mathrm{~mL})$ and acetamidinium chloride (14.00 g, $148.1 \mathrm{mmol})$ in ethanol $(90 \mathrm{~mL})$ was slowly added. The mixture was stirred for one hour at room temperature and the precipitated sodium chloride was filtered off. To the filtrate, $65 \%$ nitric acid (14.4 g, $148.1 \mathrm{mmol}$ ) was then added to the solution of acetamidine in ethanol. The product immediately precipitated. It was filtered, washed with cold ethanol and dried to yield $14.01 \mathrm{~g}$ (79.1\%). M.p. 186$188^{\circ} \mathrm{C}$.

${ }^{1} \mathrm{H}$ NMR $\left(\mathrm{D}_{2} \mathrm{O}\right) \delta: 2.20\left(\mathrm{~s}, \mathrm{CH}_{3}\right), 7.96$ (brs, $\left.\mathrm{NH}_{2}\right), 8.38$ (brs, $\left.\mathrm{NH}_{2}\right) \cdot{ }^{13} \mathrm{C}$ NMR $\left(\mathrm{D}_{2} \mathrm{O}\right) \delta: 18.4\left(\mathrm{CH}_{3}\right), 168.9(\mathrm{C}$ $\left(\mathrm{NH}_{2}\right)_{2}$. The signals of $\mathrm{NH}_{2}$ in $\mathrm{D}_{2} \mathrm{O}$ are residual signals

Table 2 NMR data for acetamidines 2, 4, 7 and 8.

\begin{tabular}{lllllll}
\hline \multicolumn{3}{l}{${ }^{\mathbf{1}} \mathbf{H} \mathbf{N M R}$} & \multicolumn{4}{c}{${ }^{\mathbf{1 3}} \mathbf{C ~ N M R}^{\mathbf{a}}$} \\
\hline Compound & $\boldsymbol{\delta}\left(\mathrm{CH}_{3}\right)$ & $\boldsymbol{\delta}\left(\mathbf{N H}_{2}\right)_{\mathbf{2}}$ & $\boldsymbol{\delta}(\mathbf{X})^{\mathbf{n}-}$ & $\boldsymbol{\delta}\left(\mathbf{C H}_{3}\right)$ & $\boldsymbol{\delta}\left(\mathbf{C}\left(\mathbf{N H}_{2}\right)_{2}\right)$ & $\boldsymbol{\delta}(\mathbf{X})^{\mathbf{n}-}$ \\
\hline $\mathbf{2}$ & $2.20^{\mathrm{a}}$ & $7.96 ; 8.38$ & & 18.4 & 168.9 & \\
& $2.10^{\mathrm{b}}$ & $8.39 ; 8.90$ & & & & \\
\hline $\mathbf{4}$ & $2.18^{\mathrm{a}}$ & $8.03 ; 8.41$ & 8.41 & 18.4 & 168.9 & 171.5 \\
& $2.06^{\mathrm{b}}$ & 9.71 & 8.42 & & & \\
\hline $\mathbf{7}$ & $2.16^{\mathrm{a}}$ & $8.04 ; 8.38$ & & 18.4 & 168.8 & 173.8 \\
\hline $\mathbf{8}$ & $2.32^{\mathrm{a}}$ & $8.00 ; 8.40$ & 18.6 & 169.0 & \\
& $2.09^{\mathrm{b}}$ & $8.30 ; 8.84$ & & & & \\
\hline
\end{tabular}

\footnotetext{
${ }^{a}$ in $\mathrm{D}_{2} \mathrm{O}$

${ }^{b}$ in DMSO-d6
}

of non-deuterated species. ${ }^{1} \mathrm{H}$ NMR (DMSO- $\mathrm{d}_{6}$ ) $\delta: 2.10$ (s, $3 \mathrm{H} \mathrm{CH}_{3}$ ), 8.39 (brs, $1.8 \mathrm{H}, \mathrm{NH}_{2}$ ), 8.90 (brs, $1.8 \mathrm{H}$ $\mathrm{NH}_{2}$ ).

Anal. Calcd for $\mathrm{C}_{2} \mathrm{H}_{7} \mathrm{~N}_{3} \mathrm{O}_{3}$ : C, 19.84; $\mathrm{H}, 5.83 ; \mathrm{N}, 34.70$. Found: C, 19.60; H, 5.77; N, 34.48.

ESI+ MS: $m / z 59\left(\mathrm{AH}^{+}\right), 117\left(\mathrm{~A}_{2} \mathrm{H}^{+}\right), 180\left(\mathrm{MAH}^{+}\right), 301$ $\left(\mathrm{M}_{2} \mathrm{AH}^{+}\right), 422\left(\mathrm{M}_{3} \mathrm{AH}^{+}\right)$. ESI- MS: $m / z$ 62((X-H) $\left.)^{-}\right), 125(\mathrm{X}$ $\left.(\mathrm{X}-\mathrm{H})^{-}\right)$, 183( $\left.\mathrm{M}(\mathrm{X}-\mathrm{H})^{-}\right), 304\left(\mathrm{M}_{2}(\mathrm{X}-\mathrm{H})^{-}\right), 425\left(\mathrm{M}_{3}(\mathrm{X}-\mathrm{H})^{-}\right)$.

Acetamidinium formate (4) A mixture of trimethyl orthoacetate (10.0 g, $83.2 \mathrm{mmol})$ and ammonium formate (10.5 g, $166.5 \mathrm{mmol}$ ) was heated under reflux for 2.5 hours. After cooling to room temperature the product was filtered, washed with cold methanol and dried to yield $5.83 \mathrm{~g}(67.2 \%)$ of white powder. M.p. $214-215^{\circ} \mathrm{C}$ (lit. [17] 214-215 $\left.{ }^{\circ} \mathrm{C}\right)$.

${ }^{1} \mathrm{H}$ NMR $\left(\mathrm{D}_{2} \mathrm{O}\right) \delta: 2.18\left(\mathrm{~s}, 3 \mathrm{H} \mathrm{CH}\right.$ ), 8.03 (brs, $\mathrm{NH}_{2}$ ), 8.41 (brs, $\mathrm{NH}_{2}$ ), 8.41 (s, $\left.1 \mathrm{H}, \mathrm{HCOO}^{-}\right) .{ }^{13} \mathrm{C} \mathrm{NMR}\left(\mathrm{D}_{2} \mathrm{O}\right) \delta$ : 18.4 $\left(\mathrm{CH}_{3}\right), 168.9\left(\mathrm{C}\left(\mathrm{NH}_{2}\right)_{2}, 171.5\left(\mathrm{HCOO}^{-}\right)\right.$. The signals of $\mathrm{NH}_{2}$ in $\mathrm{D}_{2} \mathrm{O}$ are residual signals of non-deuterated species. ${ }^{1} \mathrm{H}$ NMR (DMSO-d $\left.{ }_{6}\right) \delta: 2.06\left(\mathrm{~s}, 3 \mathrm{H} \mathrm{CH}_{3}\right), 8.42(\mathrm{~s}$, $1 \mathrm{H}, \mathrm{HCOO}^{-}$), 9.71 (brs, $3.6 \mathrm{H}_{2} \times \mathrm{NH}_{2}$ ).

Anal. Calcd for $\mathrm{C}_{3} \mathrm{H}_{8} \mathrm{~N}_{2} \mathrm{O}_{2}$ : C, 34.61; H, 7.75; N, 26.91 . Found: C, 34.90; H, 7.64; N, 26.78.

ESI+ MS: $m / z 59\left(\mathrm{AH}^{+}\right), 117\left(\mathrm{~A}_{2} \mathrm{H}^{+}\right), 163\left(\mathrm{MAH}^{+}\right), 267$ $\left(\mathrm{M}_{2} \mathrm{AH}^{+}\right), 371\left(\mathrm{M}_{3} \mathrm{AH}^{+}\right), 475\left(\mathrm{M}_{4} \mathrm{AH}^{+}\right)$. ESI- MS: $m / z 45$ $\left((\mathrm{X}-\mathrm{H})^{-}\right), 91\left(\mathrm{X}(\mathrm{X}-\mathrm{H})^{-}\right), 253\left(\mathrm{M}_{2}(\mathrm{X}-\mathrm{H})^{-}\right), 357\left(\mathrm{M}_{3}(\mathrm{X}-\mathrm{H})^{-}\right)$, $461\left(\mathrm{M}_{4}(\mathrm{X}-\mathrm{H})^{-}\right)$.

Acetamidinium oxalate (7) Acetamidinium chloride $(15.60 \mathrm{~g}, 0.165 \mathrm{~mol})$ in ethanol $(70 \mathrm{~mL})$ was slowly added to a solution of sodium ethoxide in ethanol 


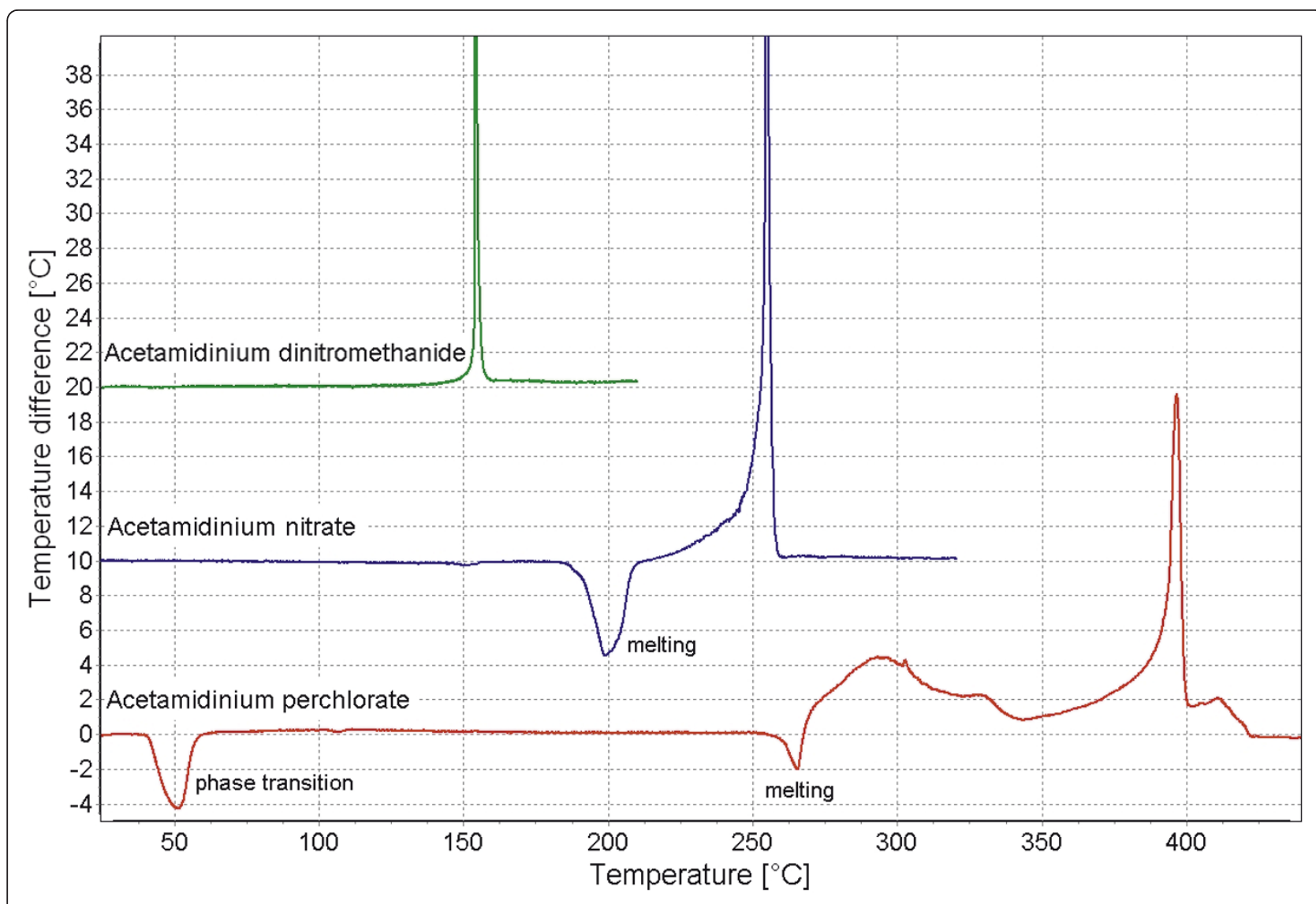

Figure 11 DTA thermograms of acetamidinium nitrate (2), acetamidinium dinitromethanide (6) and acetamidinium perchlorate (8).

(82.52 g of $12.95 \%$ solution $\sim 0.157$ mol of sodium ethoxide). The mixture was stirred for one hour at room temperature and the precipitated sodium chloride was filtered off. To the filtrate, a solution of the dihydrate of oxalic acid (9.9 g, $0.079 \mathrm{~mol})$ in ethanol $(150 \mathrm{~mL})$ was then added. The product immediately precipitated. It was filtered off, washed with ethanol and dried to yield $12.98 \mathrm{~g}(65.6 \%)$ of acetamidinium oxalate. No melting up to $360^{\circ} \mathrm{C}$.

${ }^{1} \mathrm{H}$ NMR $\left(\mathrm{D}_{2} \mathrm{O}\right) \delta: 2.16\left(\mathrm{~s}, \mathrm{CH}_{3}\right), 8.04$ (brs, $\left.\mathrm{NH}_{2}\right), 8.38$ (brs, $\left.\mathrm{NH}_{2}\right) \cdot{ }^{13} \mathrm{C}$ NMR $\left(\mathrm{D}_{2} \mathrm{O}\right) \delta: 18.4\left(\mathrm{CH}_{3}\right), 168.8(\mathrm{C}$ $\left.\left(\mathrm{NH}_{2}\right)_{2}\right), 173.8\left(\mathrm{COO}^{-}\right)$. The signals of $\mathrm{NH}_{2}$ in $\mathrm{D}_{2} \mathrm{O}$ are residual signals of non-deuterated species.

Anal. Calcd for $\mathrm{C}_{6} \mathrm{H}_{14} \mathrm{~N}_{4} \mathrm{O}_{4}: \mathrm{C}, 34.95 ; \mathrm{H} \mathrm{6.84;} \mathrm{N,}$ 27.17. Found: C, 34.93; H, 6.89; N, 27.26.

ESI+ MS: $m / z 59\left(\mathrm{AH}^{+}\right), 117\left(\mathrm{~A}_{2} \mathrm{H}^{+}\right), 207\left(\mathrm{MAH}^{+}\right), 355$ $\left(\mathrm{M}_{2} \mathrm{AH}^{+}\right), 503\left(\mathrm{M}_{3} \mathrm{AH}^{+}\right)$. ESI- MS: $m / z$ 89((X-H) $), 179(\mathrm{X}$ $\left.(\mathrm{X}-\mathrm{H})^{-}\right), 237\left(\mathrm{M}(\mathrm{X}-\mathrm{H})^{-}\right), 385\left(\mathrm{M}_{2}(\mathrm{X}-\mathrm{H})^{-}\right), 533\left(\mathrm{M}_{3}(\mathrm{X}-\mathrm{H})^{-}\right)$.

The crystals suitable for X-ray crystallography analysis were prepared by crystallisation from water using solvent evaporation at $5^{\circ} \mathrm{C}$.

Acetamidinium perchlorate (8) (A) Perchloric acid $(70 \%, 0.42 \mathrm{~mL}, 10 \mathrm{mmol})$ was slowly added to a solution of acetamidinium acetate $(1.18 \mathrm{~g}, 10 \mathrm{mmol})$ in $10 \mathrm{~mL}$ ethanol. The reaction mixture was allowed to stand to let the solvent evaporated slowly. The product crystallized in the form of colourless crystals. Yield $1.41 \mathrm{~g}$ (89\%), m.p. $268-269^{\circ} \mathrm{C}$. The crystals obtained were suitable for X-ray crystallography analysis.

${ }^{1} \mathrm{H}$ NMR $\left(\mathrm{D}_{2} \mathrm{O}\right) \delta: 2.32\left(\mathrm{~s}, \mathrm{CH}_{3}\right), 8.00$ (brs, $\left.\mathrm{NH}_{2}\right), 8.40$ (brs, $\left.\mathrm{NH}_{2}\right) .{ }^{13} \mathrm{C} \mathrm{NMR}\left(\mathrm{D}_{2} \mathrm{O}\right) \delta: 18.6\left(\mathrm{CH}_{3}\right), 169.0(\mathrm{C}$ $\left(\mathrm{NH}_{2}\right)_{2}$. The signals of $\mathrm{NH}_{2}$ in $\mathrm{D}_{2} \mathrm{O}$ are residual signals of non-deuterated species. ${ }^{1} \mathrm{H}$ NMR (DMSO- $\mathrm{d}_{6}$ ) $\delta: 2.09$ (s, $3 \mathrm{H} \mathrm{CH}_{3}$ ), 8.30 (brs, $1.8 \mathrm{H}, \mathrm{NH}_{2}$ ), 8.84 (brs, $1.8 \mathrm{H}$, $\mathrm{NH}_{2}$ ).

Anal. Calcd for $\mathrm{C}_{2} \mathrm{H}_{7} \mathrm{ClN}_{2} \mathrm{O}_{4}: \mathrm{C}, 15.15 ; \mathrm{H}, 4.45 ; \mathrm{Cl}$, 22.36; N, 17.67. Found: C, 15.41; H, 4.18; Cl, 22.71; N, 17.76.

ESI+ MS: $m / z 59\left(\mathrm{AH}^{+}\right), 217\left(\mathrm{MAH}^{+}\right), 375\left(\mathrm{M}_{2} \mathrm{AH}^{+}\right)$. ESI- MS: $m / z$ 99((X-H $\left.)^{-}\right), 257\left(\mathrm{M}(\mathrm{X}-\mathrm{H})^{-}\right), 415\left(\mathrm{M}_{2}(\mathrm{X}-\mathrm{H})^{-}\right)$.

(B) Acetamidinium sulphate $(1.07 \mathrm{~g}, 5 \mathrm{mmol})$ was dissolved in $5 \mathrm{~mL}$ water. This solution was added to a solution of barium perchlorate $(1.68 \mathrm{~g}, 5 \mathrm{mmol})$ in water $(5 \mathrm{~mL})$. The white precipitate of barium sulphate that immediately formed was filtered off. Acetamidine perchlorate was finally isolated from the aqueous 
solution using vacuum evaporation to give $0.75 \mathrm{~g}$ (95\%) of a white solid, m.p. $269-270^{\circ} \mathrm{C}$.

Anal. Calcd for $\mathrm{C}_{2} \mathrm{H}_{7} \mathrm{ClN}_{2} \mathrm{O}_{4}$ : C, $15.15 ; \mathrm{H}, 4.45 ; \mathrm{Cl}$, 22.36; N, 17.67. Found: C, 15.80; H, 4.68; Cl, 22.70; N, 17.99 .

References to procedures or availability of other salts of acetamidine Chloride (1) [31], acetate (3) [16], sulphate (5) [18], dinitromethanide (6) [19], hydrogensulphate (9) [22]

Crystallography of 7 and 8 The X-ray data for colourless crystals of $\mathbf{7}$ and $\mathbf{8}$ were obtained at $150 \mathrm{~K}$ using an Oxford Cryostream low-temperature device on a Nonius Kappa CCD diffractometer with $\mathrm{MoK}_{\alpha}$ radiation $(\lambda=$ $0.71073 \AA$ ), a graphite monochromator, and using the $\varphi$ and $\chi$ scan mode. Data reductions were performed with DENZO-SMN [32]. The absorption was corrected by integration methods [33]. Structures were solved by direct methods (Sir92) [34] and refined by full matrix least-square based on $F^{2}$ (SHELXL97) [35]. Hydrogen atoms were mostly localised on a Fourier difference map; however, to ensure uniform treatment of crystals, all hydrogens were recalculated into idealized positions (riding model) and assigned temperature factors $\mathrm{H}_{\text {iso }}(\mathrm{H})$

Table 3 Crystallographic data for acetamidinium oxalate (7) and acetamidinium perchlorate (8).

\begin{tabular}{|c|c|c|}
\hline Compound & 7 & 8 \\
\hline Empirical formula & $\mathrm{C}_{6} \mathrm{H}_{14} \mathrm{~N}_{4} \mathrm{O}_{4}$ & $\mathrm{C}_{2} \mathrm{H}_{7} \mathrm{ClN}_{2} \mathrm{O}_{4}$ \\
\hline Crystal system & orthorhombic & monoclinic \\
\hline Space group & $F d d 2$ & P 21 \\
\hline$a(\AA)$ & $17.2882(9)$ & $4.8420(3)$ \\
\hline$b(\AA)$ & $7.3029(11)$ & $10.8421(15)$ \\
\hline$c(\AA)$ & $16.7051(12)$ & $6.0140(8)$ \\
\hline$\left.\alpha=\gamma^{\circ}\right)$ & 90 & 90 \\
\hline$\beta\left(^{\circ}\right)$ & 90 & 93.709(8) \\
\hline$z$ & 8 & 2 \\
\hline$V\left(\AA^{3}\right)$ & 2109.1(4) & $315.06(6)$ \\
\hline$D_{c} / \mathrm{g} \mathrm{cm}^{-3}$ & 1.299 & 1.671 \\
\hline Crystal size (mm) & $0.32 \times 0.26 \times 0.18$ & $0.35 \times 0.25 \times 0.17$ \\
\hline Crystal shape & Colorless block & Colorless plate \\
\hline$\mu\left(\mathrm{mm}^{-1}\right)$ & 0.109 & 0.555 \\
\hline$F(000)$ & 880 & 164 \\
\hline$h ; k_{i} /$ range & $-20,20 ;-9,8 ;-21,17$ & $-5,6 ;-14,12 ;-6,7$ \\
\hline Orange $/^{\circ}$ & $3.26 ; 27.5$ & $3.39 ; 27.49$ \\
\hline Reflections measured & 2586 & 2448 \\
\hline - independent $\left(R_{\text {int }}\right)^{\mathrm{a})}$ & $1003(0.0315)$ & $1302(0.0403)$ \\
\hline - observed [I>2 $\sigma(I)]$ & 736 & 1252 \\
\hline Parameters refined & 62 & 82 \\
\hline $\operatorname{Max} / \min \Delta \rho / \mathrm{e}^{-3}$ & $0.167 /-0.211$ & $0.364 /-0.379$ \\
\hline $\mathrm{GOF}^{\mathrm{b})}$ & 1.079 & 1.071 \\
\hline$R^{c)} / W R^{c)}$ & $0.0405 / 0.0890$ & $0.0315 / 0.0766$ \\
\hline
\end{tabular}

a) $R_{\text {int }}=\Sigma\left|F_{\mathrm{o}}^{2}-F_{\mathrm{o} \text {, mean }}{ }^{2}\right| / \Sigma F_{\mathrm{o}}^{2},{ }^{\mathrm{b})} \mathrm{GOF}=\left[\Sigma\left(w\left(F_{\mathrm{o}}^{2}-F_{\mathrm{c}}^{2}\right)^{2}\right) /\left(N_{\text {diffrs }}-N_{\text {params }}\right)\right]^{1 / 2}$ for all data, $\left.{ }^{c}\right) R(F)=\Sigma|| F_{\mathrm{o}}|-| F_{\mathrm{c}}|| \Sigma\left|F_{\mathrm{o}}\right|$ for observed data, $w R\left(F^{2}\right)=\left[\Sigma\left(w\left(F_{\mathrm{o}}^{2}-F_{\mathrm{c}}{ }^{2}\right)^{2}\right) /\right.$ $\left.\left(\Sigma w\left(F_{0}^{2}\right)^{2}\right)\right]^{1 / 2}$ for all data.
$=1.2 \mathrm{U}_{\text {eq }}$ (pivot atom) or $1.5 \mathrm{U}_{\text {eq }}$ for the methyl moiety with $\mathrm{C}-\mathrm{H}=0.96$, and $0.97 \AA$ for methyl, methylene and methine hydrogen atoms, respectively. Crystallography data for $\mathbf{7}$ and $\mathbf{8}$ are given in Table 3.

Crystallography data for structural analysis have been deposited with the Cambridge Crystallographic Data Centre, CCDC no. 834605 and 834606 for 8 and 7, respectively. Copies of this information may be obtained free of charge from The Director, CCDC, 12 Union Road, Cambridge CB2 1EY, UK (fax: +44-1223-336033; e-mail: deposit@ccdc.cam.ac.uk or www: http://www. ccdc.cam.ac.uk).

Sample preparation and hygroscopicity evaluation [23] Samples weighed to within $0.1 \mathrm{mg}$ were placed in bottles with cap style stopper: The weights of the samples were 5-6 g, with the exception of acetamidinium dinitromethanide and acetamidinium perchlorate where the weight was around $1.5 \mathrm{~g}$, and dried over phosphorous pentoxide for two days. Then the samples were quickly removed to a desiccator containing 18.6\% sulphuric acid (relative humidity of $90 \%$ is thus obtained). The samples were kept at $30^{\circ} \mathrm{C}$. With 24-72 hours interval, the samples were weighed (during weighing the cap was in place).

\section{Acknowledgements}

The authors thank the Ministry of Education, Youth and Sports of the Czech Republic (within the framework of research project MSM 0021627501), the Ministry of Industry and Trade of the Czech Republic (within the framework of the research project FR-TI1/127) and the Czech Science Foundation (grant No. P206/11/0727) for financial support for this work.

\section{Author details \\ 'University of Pardubice, Faculty of Chemical Technology, Institute of Energetic Materials, Studentská 95, CZ-532 10 Pardubice, Czech Republic. ${ }^{2}$ University of Pardubice, Faculty of Chemical Technology, Department of General and Inorganic Chemistry, Studentská 95, CZ-532 10 Pardubice, Czech Republic. ${ }^{3}$ University of Pardubice, Faculty of Chemical Technology, Institute of Organic Chemistry and Technology, Studentská 95, CZ-532 10 Pardubice, Czech Republic. ${ }^{4}$ J. Heyrovský Institute of Physical Chemistry of the ASCR, v.v. i., Dolejškova 2155/3, 18223 Prague 8, Czech Republic.}

\section{Authors' contributions}

ZJ has coordinated the study, carried out the synthesis of compounds 2-7, 9, prepared a single crystal of 7 for $X$-ray analysis and drafted the manuscript. RM synthesised compound 8, prepared its crystal for X-ray analysis, provided DTA and revised the study. JO provided the hygroscopicity measurements including syntheses of the necessary amounts of all samples and revised the study. AR provided the X-ray studies and related hygroscopicity and structures. PŠ performed the NMR study and MP characterised the compounds by MS. All authors have read and approved the final manuscript.

\section{Competing interests}

The authors declare that they have no competing interests.

Received: 3 October 2011 Accepted: 12 December 2011 Published: 12 December 2011

\section{References}

1. Bredereck $H$, Effenberger $F$, Hofmann $A$ : The reactions of amidines with formylating agents: syntheses of 2, 4-disubstituted triazines. Chem Ber 1963, 96:3265-3269. 
2. Angerer S: Product class 12: pyrimidines. Science Synth 2004, 16:379-572.

3. Lagoja IM: Pyrimidine as constituent of natural biologically active compounds. Chemistry \& Biodiversity 2005, 2:1-50.

4. Schenone S, Bruno O, Radi M, Botta M: New insights into small-molecule inhibitors of Bcr-Abl. Med Res Rev 2010, 31:1-41.

5. Hu M, Wu J, Zhang Y, Oiu F, Yu Y: Synthesis of polysubstituted 5aminopyrimidines from a-azidovinyl ketones and amidines. Tetrahedron 2011, 67:2676-2680.

6. Latypov NV, Bergman J, Langlet A, Wellmar U, Bemm U: Synthesis and reactions of 1,1-diamino-2,2-dinitroethylene. Tetrahedron 1998, 54:11525-11536.

7. Dox AW, Yoder L: Pyrimidines from alkylmalonic esters and aromatic amidines. J Am Chem Soc 1922, 44:361-366.

8. Ferris LP II, Ronzio AR: A Series of 2-methyl-5-alkyl-4,6dihydroxypyrimidines. J Am Chem Soc 1940, 62:606-607.

9. Henze HR, Clegg WJ, Smart CW: Researches on pyrimidines: certain derivatives of 2-methylpyrimidine. J Org Chem 1952, 17:1320-1327.

10. Trzciński WA, Cudziło S, Chyłek Z, Szymańczyk L: Detonation properties of 1,1-diamino-2,2-dinitroethene (DADNE). J Hazar Mater 2008, 157:605-612.

11. Crossland I, Grevil FS: A convenient preparation of acetamidine. Acto Chem Scand, Ser B 1981, B35:605.

12. Norrestam $\mathrm{R}$ : Structure of bis(acetamidinium) carbonate monohydrate, 2 $\left(\mathrm{C}_{2} \mathrm{H}_{7} \mathrm{~N}_{2}{ }^{+}\right) \cdot \mathrm{CO}_{3}{ }^{2-} \cdot \mathrm{H}_{2} \mathrm{O}$, at $108 \mathrm{~K}$. Acta Crystallogr, Sect C: Cryst Struct Commun 1984, C40:297-299.

13. Pinner A: Die Imidoaether und ihre Derivative R. Oppenheim, Berlin; 1892.

14. Kopylovich MN, Kukushkin WY, Guedes da Silva MFC, Haukka M, Fraústo da Silva JJR, Pombeiro AJL: Conversion of alkanenitriles to amidines and carboxylic acids mediated by a cobalt(II)-ketoxime system. J Chem Soc, Perkin Trans 1 2001, 1569-1573.

15. Kopylovich MN, Pombeiro AJL, Fischer A, Kloo L, Kukushkin WY: Facile Ni(II)/ ketoxime-mediated conversion of organonitriles into imidoylamidine ligands. synthesis of imidoylamidines and acetyl amides. Inorg Chem 2003, 42:7239-7248.

16. Taylor EC, Ehrhart WA: A convenient synthesis of formamidine and acetamidine acetate. J Am Chem Soc 1960, 82:3138-3141.

17. Krechl S, Böehm S, Smrčková J, Kuthan J: Simple amidinium carboxylatesan MO treatment of molecular geometry and electronic structure. Collect Czech Chem Commun 1989, 54:673-683.

18. Jalový Z, Růžička A: Diacetamidinium sulfate. Acta Cryst Sect E: Struct Rep Online 2011, E66:3346-3347.

19. Jalový Z, Ottis J, Růžicka A, Lyčka A, Latypov NV: Organic salts of dinitromethane. Tetrahedron 2009, 65:7163-7170.

20. Gautier J-A, Miocque M, Farnoux CC: Preparation and synthetic use of amidines. In The chemistry of amidines and imidates. Edited by: Patai S. John Wiley 1975:283-348.

21. Granik VG: Uspechi chimii amidinov. Usp Khim 1983, 52:669-703.

22. Jalový Z, Mareček P, Dudek K, Fohl O, Latypov NV, Ek S, Johansson M: Improved synthesis of 2-(dinitromethylene)-4,5-imidazolidinedione. New Trends in Research of Energetic Materials 8 Pardubice, Czech Republic; 2005, 579-583.

23. Department of Defense: Method 208.1 Hygroscopicity (Equilibrium method). MIL-STD-650 Military standard: Explosive; sampling, inspection and testing Department of defense armed forces support center. Washington, DC; 1962.

24. Norrestam R, Mertz $\mathrm{S}$, Crossland I: Structure of acetamidine, $\mathrm{C}_{2} \mathrm{H}_{6} \mathrm{~N}_{2}$, at 108 K. Acta Crystallogr, Sect C: Cryst Struct Commun 1983, 39:1554-1556.

25. Ferretti $V$, Bertolasi $V$, Pretto L: Supramolecular aggregation by means of charge-assisted hydrogen bonds in acid-base adducts containing amidinium cations. New J Chem 2004, 28:646-651.

26. Cannon JR, White AH, Willis AC: Crystal structure of acetamidinium chloride. J Chem Soc, Perkin Trans 2 1976, 271-272.

27. Tominey AF, Docherty PH, Rosair GM, Quenardelle R, Kraft V: Unusually weak binding interactions in tetrazole-amidine complexes. Org Lett 2006 8:1279-1282

28. Calov $U$, Jost K-H, Leibnitz P: Acetamidinium hexafluorometalates of silicon, germanium, tin, and titanium. Z Anorg Allg Chem 1990, 589:199-206.

29. Emirdag-Eanes $M$, Ibers JA: Conversion of a $\operatorname{Re}(\mathrm{IV})$ tetrahedral cluster to a $\mathrm{Re}(\mathrm{III})$ octahedral cluster: synthesis of $\left[\left(\mathrm{CH}_{3}\right) \mathrm{C}\left(\mathrm{NH}_{2}\right)_{2}\right]_{4}\left[\mathrm{Re}_{6} \mathrm{Se}_{8}(\mathrm{CN})_{6}\right]$ by a solvothermal route. Inorg Chem 2002, 41:6170-6171.
30. Gottlieb HE, Kotlyar V, Nudelman A: NMR chemical shifts of common laboratory solvents as trace impurities. J Org Chem 1997, 62:7512-7515.

31. Sigma-Aldrich Corporation: Aldrich chemistry: handbook of fine chemicals 2009-2010. Sigma-Aldrich: St. Louis, MO; 2010.

32. Otwinowski Z, Minor W: Processing of X-ray diffraction data collected in oscillation mode. Methods in Enzymology 1997, 276:307-326.

33. Coppens $P$ : The evaluation of absorption and extinction in single-crystal structure analysis. In Crystallographic Computing. Edited by: Ahmed FR, Hall SR, Huber CP. Copenhagen: Munksgaard; 1970:255-270.

34. Altomare A, Cascarano G, Giacovazzo C, Guagliardi A: Completion and refinement of crystal structures with SIR92. J Appl Crystallogr 1993 26:343-350.

35. Sheldrick GM: SHELXL-97. University of Göttingen, Göttingen, Germany; 1997.

doi:10.1186/1752-153X-5-84

Cite this article as: Jalový et al:: Synthesis and properties of acetamidinium salts. Chemistry Central Journal 2011 5:84

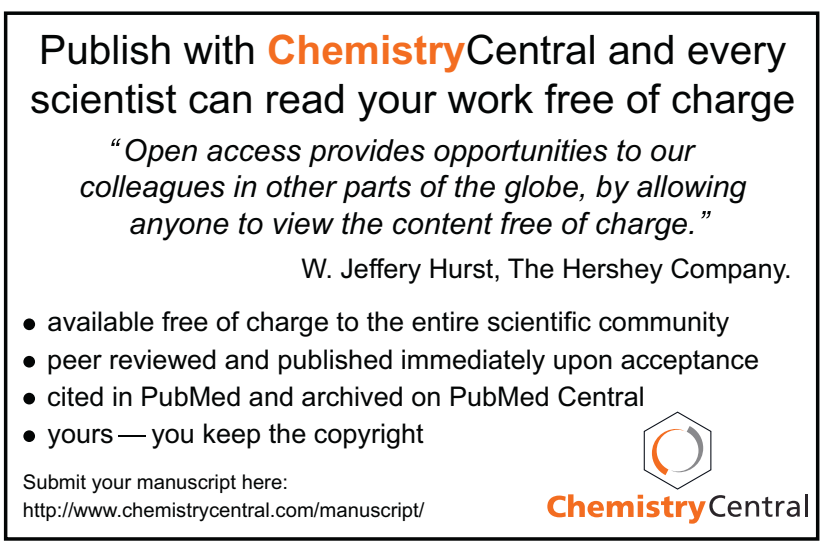

